\title{
Covid-19 and transformational megatrends in the European automotive industry: Evidence from business decisions with a Central and Eastern European focus
}

\author{
Anita Pelle, Gabriella Tabajdi
}

\section{A B S T R A C T}

Objective: The objective of the article is to reveal the effects of the Covid-19 pandemic on the businesses in the European automotive sector, with a special focus on Central and Eastern Europe. The further objective is to identify how these effects relate to the ongoing transformational megatrends in the sector (digitalisation, electrification).

Research Design \& Methods: We have collected a large (>700 items) sample of relevant business decisions in the European automotive sector over four years (2017-2021), including those taken especially due to the Covid-19 pandemic. In our research, we transformed our qualitative inputs into a quantitatively analysable database through coding. Then, we applied descriptive statistical analysis on the retrieved data combined with qualitative analysis of the contents behind these data.

Findings: Based on our sample, our primary finding is that the Covid-19 pandemic does trigger the already existing trends of digitalisation and electrification in the European automotive sector. Very similar effects characterise the relatively less developed but deeply integrated Central and Eastern European periphery, although to a lesser extent. Obviously, the Covid-19 pandemic has induced numerous temporary business decisions, mainly plant closures. Layoffs occurred as well but these were not prevalent. Then, the second wave of the pandemic in early 2021 brought about the global shortage of semiconductor chips, which substantially affected the sector in Europe.

Implications \& Recommendations: The longer lasting impact of the short-term pandemic-related European automotive business decisions is yet to be explored. Nevertheless, the global shortage of semiconductor chips is already showing signs of influencing the industry over a longer time scale, in Europe as well. Forward-looking, future-oriented, and brave responses to the pandemic can well be the keys for businesses to successfully overcome the negative effects of the Covid-19 pandemic.

Contribution \& Value Added: Our sample of more than 700 items and a four-year-long timespan is in itself a unique collection of business decisions in the European automotive sector. In addition, by processing the inputs through coding, our sample becomes a treasury of potential information. In this article, we conduct an exploration along the events to which the decisions can be related, and along the decision types. We also look at the involvement of Central and Eastern Europe. Obviously, our ongoing primary research was ready to be extended to the firm level analysis of the effects of the Covid-19 pandemic, immediately upon its outburst.
Article type:
research article
Keywords:
Covid-19; automotive industry; Central and Eastern Europe; digitalisation; electrification
JEL codes: F23, O14, F15

Received: 30 March 2021 Revised: 2 June 2021 Accepted: 15 July 2021

\section{Suggested citation:}

Pelle, A., \& Tabajdi, G. (2021). Covid-19 and transformational megatrends in the European automotive industry: Evidence from business decisions with a Central and Eastern European focus. Entrepreneurial Business and Economics Review, 9(4), 19-33. https://doi.org/10.15678/EBER.2021.090402 


\section{INTRODUCTION}

The European automotive industry has been going through substantial transformation over the past years due to digitalisation and the shift towards lower emission engine solutions, mainly electrification - these can be considered as the megatrends that currently shape the industry. However, the ongoing transformation has recently been affected by Covid-19. As a result of the pandemic, the overall GDP of the EU dropped significantly (by $6.2 \%$ in 2020), accompanied by a substantial decrease in consumption $(-4.5 \%)$ and investments $(-4.25 \%)$ (EC, 2021). On the one hand, the pandemic has undoubtedly disrupted global value chains (GVCs) (Betti \& Hong, 2020). On the other hand, it has given further impetus to the already traceable changes both in the core EU member states (Western and Northern old members of the EU) and in the periphery, including Central and Eastern Europe (CEE), not to mention the Southern Eurozone countries (Simonazzi, Sandinés, \& Russo, 2020).

Our objective is to reveal the effects of the Covid-19 pandemic on the businesses in the European automotive sector, with a special focus on CEE. Our further objective is to identify how these effects relate to the ongoing transformational megatrends in the sector (digitalisation, electrification). To such ends, we analysed a self-collected sample of business decisions through coding. We found no similar research in terms of method, industrial scope, or overall size, so our work can be considered original and novel.

In our research, we sought answers to the following questions. How has the Covid-19 pandemic affected the European automotive industry? Do the trends in CEE align with those in respect of the complete European sector? How does the impact of the Covid-19 pandemic interfere with the ongoing megatrends of transformation (i.e. digitalisation and electrification) in the automotive industry globally and in Europe?

Our study starts with a literature review covering the latest trends in the automotive industry, the automotive sector in Central and Eastern Europe, and the impact of the Covid-19 pandemic on the sector. Then, we describe our research methodology including our sample and coding. Next, we provide a discussion and our results with respect to Covid-19 and the automotive sector in Europe with a focus on CEE. Moreover, we seek to indicate the interference of the pandemic with sectoral megatrends. Our conclusions reflect on literature and own findings along these dimensions.

\section{LITERATURE REVIEW}

We focus here on the European and, specifically, Central and Eastern European automotive industry. The automotive industry is one of the fastest growing industries in Europe; it is a significant employer and investor, and it is one of the most determinant industrial sectors of the EU (Drelich-Skulska \& Bobowski, 2021). Due to its high technology needs, the industry has a traditionally crucial role in research and development (R\&D), besides production. Thus, it is an essential innovator and has serious investment capacities (Vosta \& Kocourek, 2016). The European automotive industry consists of more than 20000 enterprises, produces ca. 7\% of the EU's GDP, accounts for $8.3 \%$ of manufacturing employment, and for $6 \%$ of total employment. Moreover, European production is responsible for $20 \%$ of the global sectoral output. All this emphasises the industry's importance in Europe's economy and Europe's global prominence (Vosta \& Kocourek, 2016, ACEA, 2018).

In the past years, a strong restructuring of production from the old towards the new EU member states has been going on to exploit possible advantages. The CEE countries' relevance is growing with respect to production and trade since their accession to the EU (Ricci, 2019). These countries continue to be considered as preferred locations for automotive firms.

The automotive industry of the CEE region highly depends on foreign capital, which is the basis for its high technological development level (Farkas, 2011; Pavlínek, Aláez-Aller, Gil-Canaleta, \& UllibarriArce, 2017). The rapid development of the sector in CEE is driven by transnational corporations (TNCS) headquartered in the core of the EU, who control the CEE region through direct ownership of both assembly plants and suppliers. The region's automotive industry is concentrated mostly in Czechia, 
Poland, Hungary, and Slovakia (i.e. the Visegrad countries), but also to a growing extent, in Romania (Pavlínek et al., 2017). This position was acquired through foreign direct investment (FDI), and the region, especially the Visegrad country group, remains among the most attractive locations for investment (Dorożyński, Dobrowolska, \& Kuna-Marszałek, 2020; Makieła, Wojciechowski \& Wach, 2021). At the same time, this attractiveness has contributed to the evolution of these countries, dependency on the Western European core (Nölke \& Vliegenthart, 2009) and has enhanced the vulnerability of these economies in times of crisis.

Automotive firms have several reasons to prefer CEE countries; one of them is geographical proximity, specifically to Germany (Belniak, 2015; Pavlínek, 2015). A further reason is the relatively low wage level, combined with qualified workforce and industrial traditions (Pavlínek \& Guzik, 2009; Rechnitzer, Hausmann \& Tóth, 2017). The relatively stable political system and the accession to the EU were also key factors, together with the FDI-friendly environment and various investment incentives. In addition, flexible labour laws and weak trade unions compared to Western Europe add to their popularity for FDIs (Pavlínek, 2015; Cieślik, 2017; Götz, Jankowska, Matysek-Jędrych, \& Mroczek-Dąbrowska, 2018).

Today, the automotive industry undoubtedly plays an influential role in the economy of the CEE countries through its impact on production, employment, value added, and export. Moreover, it has multiplier effects through its significant connecting supplier base that contributes to the competitiveness of the small and medium-sized enterprises in the region and has considerable modernisation effects (Molnár, 2013).

However, the automotive sector has recently been determined primarily by digitalisation and electrification, both globally and in Europe. The automotive industry has increasingly moved towards automation in production and the growing use of IT solutions (digitalisation), while due to $\mathrm{CO}_{2}$ emission standard modifications and climate change mitigation efforts, car manufacturers began to direct their development capacities towards hybrid and electric car production (electrification). For decades, cars with internal combustion engines were dominant; however, alternative, mainly electricity-based solutions are emerging, and their market share is steadily increasing (Casper \& Sundin, 2020).

Digitalisation affects society and business alike. As far as business is concerned, digital technologies allow for the development of new, innovative (e.g. platform-based) business models or the use of decentralised models through blockchain or 3D printing. Digitalisation may also lower entry barriers, sometimes cross-industry, potentially leading to the emergence of innovative IT companies as new competitors, even in traditional industries such as the automotive industry (Urbach \& Röglinger, 2018). These shifts are likely to change the global structure of industrial production, in part through competitors from emerging countries and from other industries (e.g. ICT firms) (Simonazzi et al., 2020).

The ongoing transformation does not only result in production restructuring but also in the reorganisation of GVCs between well-established firms and new entrants. This affects location advantages, the regionalisation of production, and the distribution of labour in general. Importantly, Covid-19 is likely to further accelerate these changes (Simonazzi et al., 2020).

As an accompanying phenomenon, there is an emerging trend of establishing partnerships due to electrification and digitalisation as automotive firms fear falling behind in competition. Many such strategic partnerships of car makers aim at sharing costs and risks arising from the development and application of more advanced and cleaner technologies, but also to share their knowledge (Giffi, Vitale, Schiller, \& Robinson, 2020; Dutt, Natarajan, Wilson, \& Robinson, 2020). Similar reasons motivate the acquisition of innovative digital firms by car manufacturers. The Covid-19 pandemic has clearly given an additional impetus to such acquisitions (Simonazzi et al., 2020).

Nevertheless, the Covid-19 pandemic has mainly affected the European automotive industry (and especially CEE) through global value chains. The impact could already be identified when the pandemic was just China's problem (Kinnunen, Georgescu, Hosseini, \& Androniceanu, 2021). Over the years, China and especially Wuhan, where the coronavirus was first detected, had become an important supplier of intermediate products to the global automotive industry. Thus, any major disruption in Chinese supply was to have a significant impact on manufacturers globally (UNCTAD, 2020a). During the spring of 2020, GVCs actually suffered sudden disruptions, with significant consequences for businesses, con- 
sumers, and the global economy. Due to the outbreak of the pandemic, and the related declining demand, supplier problems, and government decisions, many companies decided to close factories or significantly reduce production. This is especially true for the automotive industry whose just-in-time production system was quickly disturbed by production suspensions (Betti \& Hong, 2020). In June 2020, the average closure time for car factories in the EU and the United Kingdom was around 30 days, and slightly lower in CEE with 28 days (ACEA, 2020a). Shutdowns made production capacities unable to recover to pre-crisis levels by the end of 2020, which had resulted in production losses in the EU amounting to more than 4.2 million vehicles or $22.9 \%$ of 2019 vehicle production. The loss was the largest for Germany (1.19 million vehicles), followed by France and Spain. In the CEE region, the most significant drop in production occurred in Czechia and Poland (ACEA, 2020b).

Supply problems intensified as the virus entered Europe, especially in CEE as production here is highly dependent on intermediates from the EU (especially Germany). Moreover, these countries were also affected by the demolishing of value chains on the export side as a significant part of their automotive production is intended for export (Leering \& Spakman, 2020). CEE countries are actually largely exposed to GVC shocks, mainly through their integration in the German automotive supply chain (Demertzis \& Masllorens, 2020).

Although production restarted gradually following the first shock in early 2020, the negative effects were clear. However, we should mention two benefits of GVC shocks caused by the Covid-19 pandemic. Firstly, to improve the resilience of supply chains, some activities previously placed abroad may be transferred back to Europe, thus shortening GVCs (UNCTAD, 2020b). Another benefit of the pandemic may be that the use of advanced, new manufacturing technologies can provide flexible responses to possible future shocks (Betti \& Hong, 2020).

Based on the literature, we formulate the following research hypotheses:

H1: The Covid-19 pandemic fundamentally affected the European automotive industry, amidst the ongoing sectoral megatrends of digitalisation and electrification.

H2: The trends and effects in Central and Eastern Europe are in line with those identified at the European level.

H3: Interference between the effects of the pandemic and the sectoral megatrends may well yield unexpected advancements; in particular, businesses may take the pandemic-induced crisis as an opportunity to engage in transformation.

\section{RESEARCH METHODOLOGY}

We conducted our empirical research based on a self-collected database consisting of relevant business decisions. The sources of our inputs were international and Hungarian business news portals (international: Reuters, Bloomberg; Hungarian: Portfolio, HVG) that report on companies' press conferences and public announcements. Our full sample contained 703 items that were in fact announcements of 166 firms related to the automotive industry ( 578 items), and further announcements at the industry or country level (51 and 74 items, respectively). The timeframe of the dataset was March 2017 - February 2021 (i.e. four years); however, most of the announcements were from $2020(46.23 \%)$ and 2019 (26.74\%). The larger weight of 2020 in the sample can be partly attributed to the pandemicrelated announcements. Overall, our sample was incomplete and not representative, although we strove for its largest possible width and depth.

Our applied research method was fundamentally a quantitative descriptive analysis of a coded database of qualitative inputs. Coding can be understood as the conversion of raw qualitative information into communicative and reliable quantitative data. In coding, we labelled the items of our empirical dataset with words or short phrases that well summarised their contents. The reduction of the large amount of empirical material, thus making the data ready for immediate analysis, is a great advantage of coding and the main reason for its use (Böhm, 2004; Linneberg \& Korsgaard, 2019). Coding always consists of multiple rounds. The first round of coding is performed on a certain amount of pre-existing data (Saldaña, 2009; 2015). Coding provides a comprehensive and thorough 
insight in our dataset as it makes data easily accessible and retrievable, and it ensures transparency and validity (Linneberg \& Korsgaard, 2019).

We coded our sample along the following dimensions: topic of the decision, firm type (Original Equipment Manufacturer called OEM, or supplier), location concerned by the decision (country, the EU, globe), nationality of firm, CEE involvement (yes/no), decision type (Figure 1).
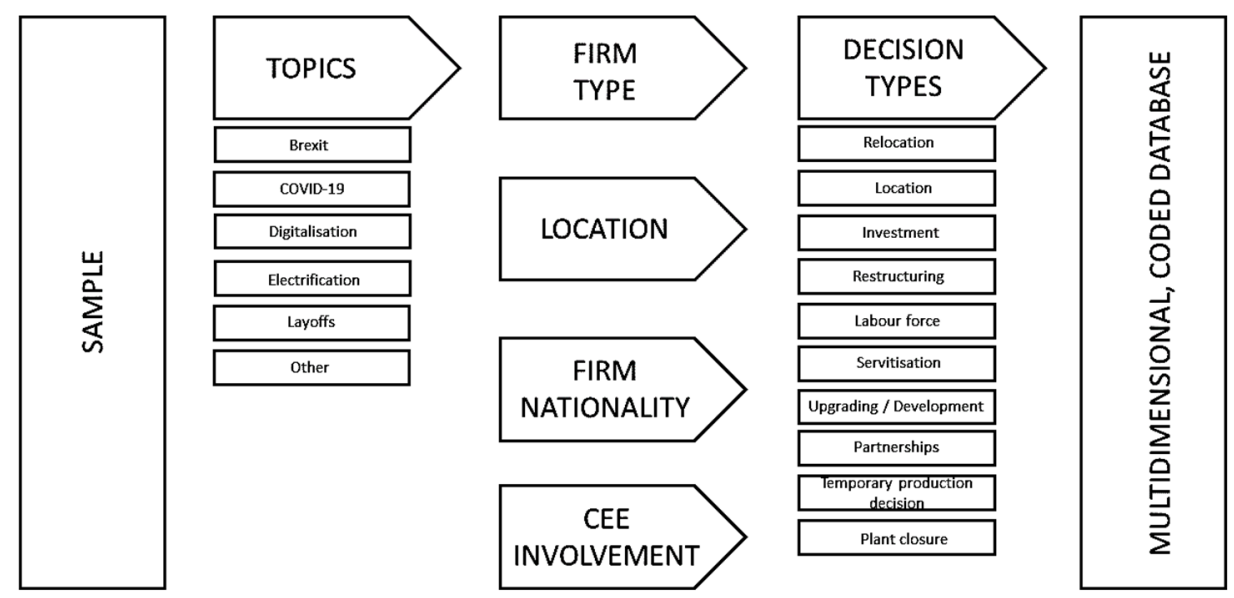

Figure 1. The coding of our sample of business decisions in the European automotive industry Source: own elaboration.

In the first round of coding, we classified every element of our sample into the topics that we defined as the following: Brexit, digitalisation, electrification, layoff, Covid-19, and an 'other' category that consisted of announcements relevant for the European automotive industry but not belonging to either of the specified topics (e.g. announcements of site expansions or new production facilities). When coding and evaluating each announcement, we sought particular decisions made by industrial actors. Regarding decision types, we defined the categories of relocation, new location (be it a production site or an R\&D centre), investment, restructuring (mostly business), labour force (layoffs, changes in labour cost, remuneration), servitisation, upgrading/development, partnership, temporary production decision (shutdowns and restart of production), and (terminal) plant closure. As a result of coding, we received a 962-line, multidimensional, coded, and therefore quantified database from our 703item sample, now ready to be analysed with descriptive statistical methods.

\section{RESULTS AND DISCUSSION}

In our analysis, we combined statistics with qualitative inquiry into the contents. Our investigation focused on the topics of the business announcements, firm characteristics and location, decision types, CEE involvement, and last but not least, the Covid-19 pandemic.

\section{Business announcements: Topics}

First, we checked our database along the topics of business announcements (Figure 2). Many entries belonged to two categories: these were considered twice. Most of the entries were connected to electrification (281), the Covid-19 pandemic (205), and digitalisation (133).

Let us provide some qualitative details regarding the contents behind the inputs. In the electrification category, most of the items were firm- or industry-level decisions on the planned timing of full shift to electric engines in production and retail or the planned timing of switching the majority of produced cars to electric. The pandemic-related inputs were typically related either to lockdowns and restrictions or value chain restructuring, but there were also examples for announcements on state aid and other policy measures. Within digitalisation, autonomous driving and the appearance of IT firms in the sector prevailed. The categories of layoff and Brexit require no further explanation. The 
group of 'other' announcements was dominated by location decisions, many times concerning new establishments and CEE as the location.

Regarding those items that belong to two categories, the parallel involvement of electrification and Covid-19 (27 items) pointed to two main connections. On the one hand, the global chip shortage caused by Covid-19-induced delays in electric vehicle production. On the other hand, many traditional companies (e.g. Volkswagen) escaped forward from the Covid-19-induced economic crisis and accelerated the production and sale of their electric models. Electrification and digitalisation ( 22 items) together covered partnerships aiming at exploiting the opportunities in both dimensions, and developments where digital technologies were applied in electrification (e.g. the Internet of Things, robotisation, production process optimisation). The combination of Covid-19 and layoffs (25 items) or Brexit and layoff ( 9 items) was rather obvious. Electrification and layoff ( 13 items) might have occurred jointly as electric vehicles consist of fewer spare parts hence need less labour input in their production. The rest of such dual cases was negligible in share and importance.

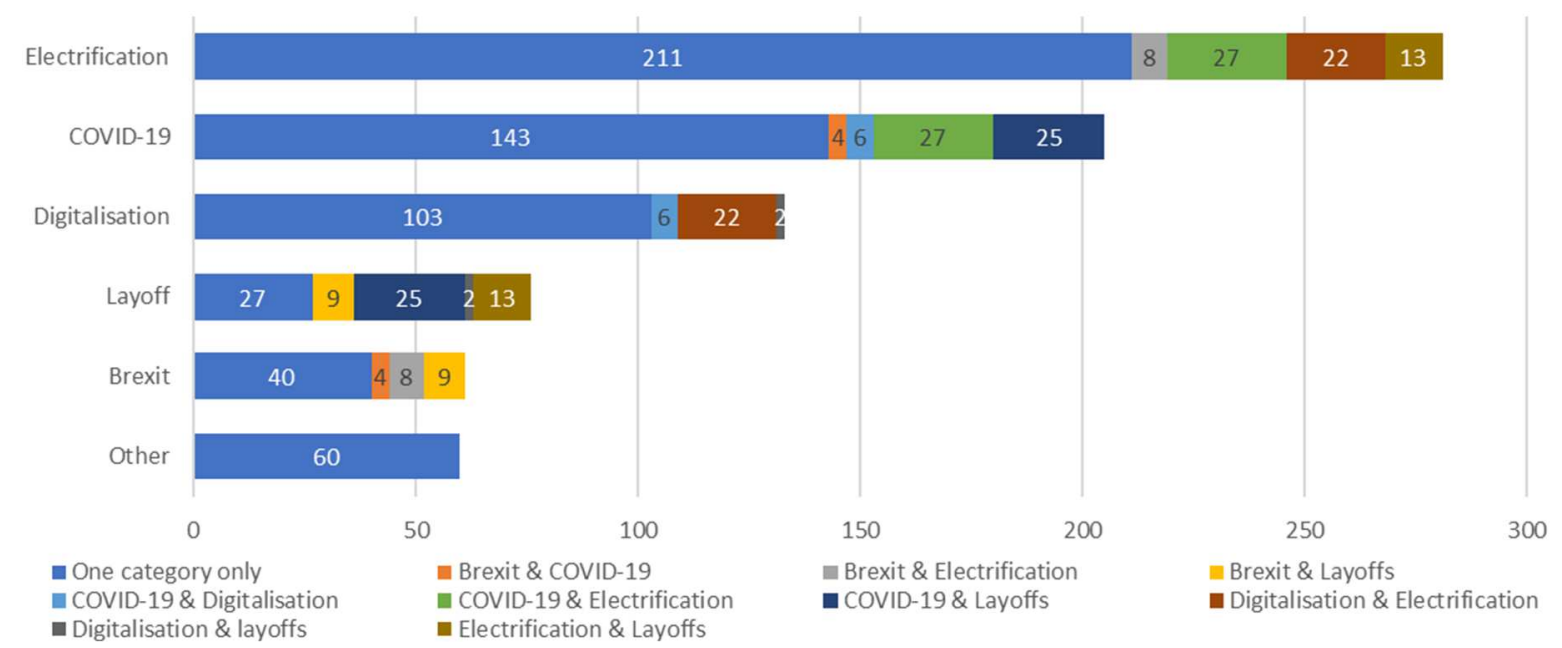

Figure 2. Business announcements by topics (number)

Source: own elaboration.

\section{Business announcements: Decision types}

We analysed business announcements concerning different decision types to see their impact. When coding decision types, one announcement often belonged to more than one category, but in certain cases, we could not relate the entry to any of them (99 items, mostly in connection with electrification and Covid-1919.

In decision type breakdown, many of the announcements in our sample could be connected to upgrading/development (20.62\%), investment (19.18\%), and labour force (15.41\%), while the least frequent decision types were plant closures and relocations.

We were interested in how electrification, digitalisation, Brexit, the Covid-19 pandemic, and other events were connected to the types of decisions made by businesses and other stakeholders (Table 3).

In the case of the Covid-19 pandemic, more than half of the related decisions in our dataset were temporary production decisions. During the waves of the pandemic, many companies decided to conduct shutdowns to preserve the health of their employees, but also because demand for new vehicles decreased or breakages in their global value chains caused problems of certain parts supply. In the first months of 2021, there was a second wave of such temporary production decisions due to the global shortage of semiconductor chips forcing automotive firms to decrease production volumes.

\footnotetext{
${ }^{1}$ The reason why we could not relate these entries to any of the defined decision categories is that the majority of these announcements are either in connection with sales drop (mostly for Covid-19), increased competition (for electrification) or state related announcements like financial help for automotive firms suffering from the impacts of Covid-19.
} 
Regarding digitalisation, decisions related to upgrading/development and partnership formed the majority of our dataset. We may attribute this to the fact that digitalisation brings development, and many of the automotive industry's actors try to leverage on partnerships either with another automotive firm or, actually, in many cases, with ICT firms. However, somewhat strikingly, no firm in our sample announced decisions in connection with possible relocation. This is specifically notable from the viewpoint of CEE due to the fear of possible backshoring of activities to countries with higher purchasing power or larger cohorts of consumers.

Table 1. Business decisions, breakdown by main topic (number)

\begin{tabular}{|c|c|c|c|c|c|c|c|c|c|c|c|}
\hline Topic & 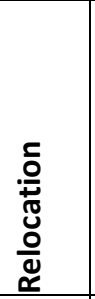 & كَ & 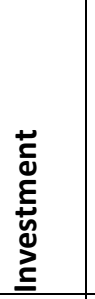 & 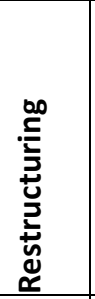 & 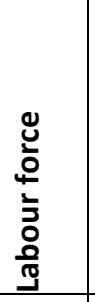 & 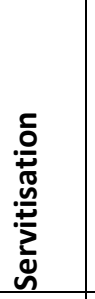 & 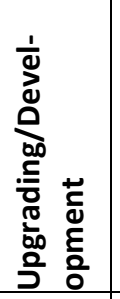 & 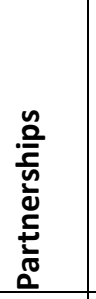 & 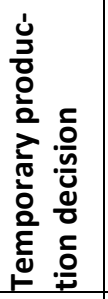 & 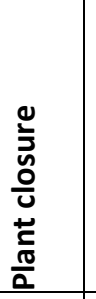 & $\begin{array}{l}\bar{\pi} \\
\stackrel{0}{0} \\
\stackrel{-}{*}\end{array}$ \\
\hline Brexit & 11 & 2 & 11 & 2 & 11 & 0 & 4 & 0 & 10 & 4 & 55 \\
\hline Covid-19 & 2 & 2 & 10 & 6 & 37 & 0 & 5 & 4 & 103 & 1 & 170 \\
\hline Digitalisation & 0 & 7 & 27 & 6 & 12 & 25 & 65 & 54 & 0 & 0 & 196 \\
\hline Electrification & 3 & 33 & 91 & 19 & 26 & 5 & 102 & 47 & 1 & 5 & 332 \\
\hline Layoffs & 3 & 0 & 0 & 3 & 29 & 0 & 1 & 0 & 0 & 3 & 39 \\
\hline Other & 3 & 20 & 34 & 6 & 24 & 0 & 9 & 6 & 4 & 4 & 110 \\
\hline Total & 22 & 64 & 173 & 42 & 139 & 30 & 186 & 111 & 118 & 17 & 902 \\
\hline
\end{tabular}

Source: own study.

As for electrification, upgrading/development and investment decisions dominated. Investment often concerned a new location. Partnerships were also frequent in electrification decisions, yet these mostly referred to partnerships between automotive firms to exploit the benefits of cooperation.

Obviously, the labour force was strongly connected to layoffs. For the 'other' category, investment decisions had the largest share. In fact, these were investments not connected to either of the other main themes but are important specifically for the CEE region, e.g. enhancing production capacities, opening a new unit of production, typically with lower value added.

\section{Firm-related characteristics and location}

The majority of the announcements in our dataset were of OEMs (61.04\%), while $25 \%$ were of suppliers. The remaining $13.96 \%$ concerned certain countries' industries rather than any explicit firm. In these cases, both OEMs and suppliers were likely affected. We also analysed the decision breakdown by OEMs (583) and suppliers (330) (Table 4). For relocation, restructuring, upgrading/development, temporary production decisions, and plant closure, OEMs were overrepresented. For location decisions, suppliers actually outweighed OEMs in the sample, implying that mostly suppliers have chosen to invest in new locations. Actually, more than half of their investment decisions can be linked to a new location while the same figure is much lower for OEMs. OEMs' decisions are mostly connected to upgrading/development, partnerships, and investment.

In a company breakdown, the Volkswagen (VW) Group is overrepresented in the sample with $18.03 \%$ of entries (mostly VW and Audi). BMW (7.75\%) and Daimler Mercedes-Benz (7.61\%) follow the VW Group. However, suppliers made fewer announcements, the ones accounting for most entries in our database were Continental, Bosch, and Thyssenkrupp. These numbers suggest that German automotive firms are heavily represented in our sample and are responsible for a large share of the announcements (Table 3 ). Altogether, $40 \%$ of the entries were connected to German automotive firms. What dominated in main topic breakdown were German automotive announcements on electrification, digitalisation, and the Covid-19 pandemic.

Because we partly focused on CEE, we also checked its involvement. In fact, $27.6 \%$ of the sample related to CEE, mostly for Covid-19 and electrification. 
Table 2. Business decisions made by OEMs and suppliers, by type (number)

\begin{tabular}{|c|c|c|c|c|c|c|c|c|c|c|c|}
\hline Types & 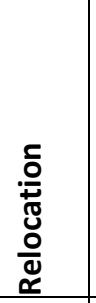 & 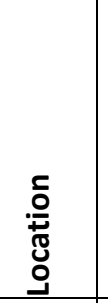 & 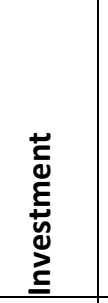 & 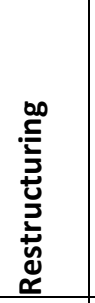 & 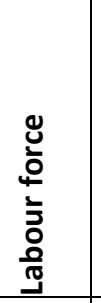 & 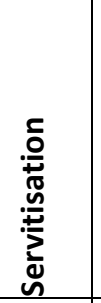 & 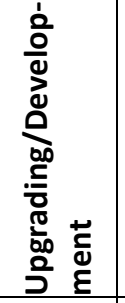 & 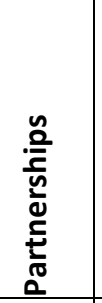 & 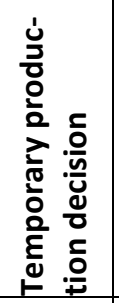 & 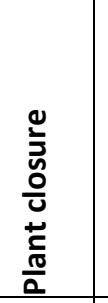 & $\begin{array}{l}\bar{\pi} \\
\stackrel{0}{0}\end{array}$ \\
\hline OEM & 18 & 23 & 93 & 34 & 73 & 20 & 125 & 98 & 85 & 14 & 583 \\
\hline Supplier & 3 & 39 & 78 & 5 & 48 & 16 & 63 & 65 & 11 & 2 & 330 \\
\hline Neither & 1 & 3 & 9 & 3 & 19 & 2 & 19 & 1 & 22 & 1 & 80 \\
\hline
\end{tabular}

Source: own study.

Table 3. Entries related to CEE and German automotive firms (number)

\begin{tabular}{|l|r|r|r|}
\hline \multicolumn{1}{|c|}{ Firms } & CEE & German automotive firms & Both \\
\hline Brexit & 0 & 7 & 0 \\
\hline Covid-19 & 64 & 58 & 19 \\
\hline Digitalisation & 26 & 58 & 7 \\
\hline Electrification & 59 & 119 & 27 \\
\hline Layoff & 7 & 20 & 6 \\
\hline Other & 38 & 22 & 16 \\
\hline Total & 194 & $\mathbf{2 8 4}$ & $\mathbf{7 5}$ \\
\hline
\end{tabular}

Source: own study.

As a further dimension, we looked at the location affected by the announcements. The locations most represented in our sample were Germany and Hungary, followed by the United Kingdom. Many decisions had a global and European effect. Outside Europe, the United States of America, Japan, and China were the most frequently concerned locations. Yet, as mentioned above, our sample was not representative.

Looking at the different decisions affecting the CEE region, electrification prevailed followed by the 'other' category, here covering mostly new investments and, in many cases, new locations in the region. Notably, these were not digitalisation-, electrification-, or pandemic-related investments but other types, mostly investments of suppliers targeting development, capacity enhancement, or new production plants. Nevertheless, this was a signal that the CEE remained an attractive location, even in times of fundamental changes and the pandemic. In this subset, we found no Brexit-related announcements. For the Covid-19 pandemic, temporary production decisions and measures related to labour force dominated the dataset, mostly covering layoffs and reduced working hours. Based on our sample, digitalisation and electrification affected the region primarily through upgrading/development and investments. In addition, numerous new location decisions were made that related directly to electrification. Apparently, firms invested in the modernisation of their branches in CEE instead of moving them to the West.

\section{Business announcements and Covid-19, with a CEE focus}

After analysing the whole sample, we removed the entries connected solely to Brexit, layoffs, electrification, digitalisation, or other and undertook a deep analysis regarding the subset of the pandemicrelated entries, which consisted of 205 elements.

The timeframe for this subset was March 2020 - February 2021. The start of the period was obvious as Covid-19 appeared in the majority of the EU countries in March 2020, substantially affecting our lives, including industrial production. In particular, most entries were from March, April, and May 2020 , adding up to $57.87 \%$ of all pandemic-related cases. The reason for this was that the first wave of the pandemic hit automotive firms hard: GVCs were disrupted, employers were concerned about the 
health of employees, and they had no protocol for such an event. Nevertheless, in January and February 2021, a new wave of announcements occurred (20.3\% of total Covid-19 entries in our dataset) due to the global shortage of semiconductor chips.

Table 4. CEE related decisions by main topic breakdown and by decision type (number)

\begin{tabular}{|c|c|c|c|c|c|c|c|c|c|c|c|}
\hline Types & 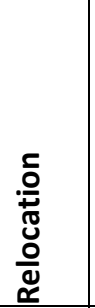 & 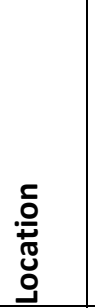 & 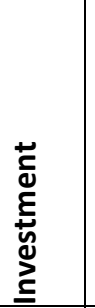 & 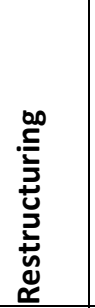 & 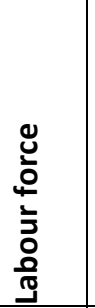 & 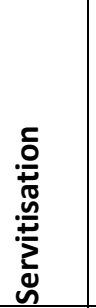 & 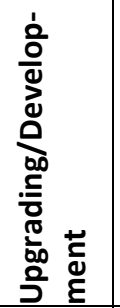 & 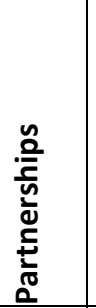 & 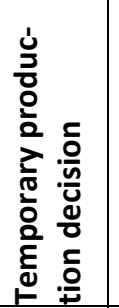 & 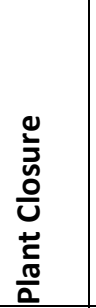 & 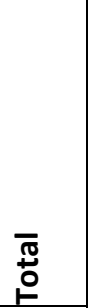 \\
\hline Brexit & 0 & 0 & 0 & 0 & 0 & 0 & 0 & 0 & 0 & 0 & 0 \\
\hline Covid- 19 & 0 & 2 & 7 & 2 & 15 & 0 & 2 & 0 & 37 & 0 & 65 \\
\hline Digitalisation & 0 & 6 & 16 & 1 & 6 & 1 & 21 & 1 & 0 & 0 & 52 \\
\hline Electrification & 3 & 22 & 40 & 5 & 13 & 0 & 24 & 0 & 0 & 1 & 108 \\
\hline Layoffs & 3 & 0 & 0 & 2 & 7 & 0 & 0 & 0 & 0 & 1 & 13 \\
\hline Other & 2 & 18 & 29 & 2 & 20 & 0 & 0 & 0 & 2 & 0 & 73 \\
\hline Total & 8 & 48 & 92 & 12 & 61 & 1 & 47 & 1 & 39 & 2 & 311 \\
\hline
\end{tabular}

Source: own study.

Our database gathered 43 firms overall making decisions in connection with the Covid-19 pandemic, but this number hid the fact that, in many cases, entries referred to the automotive industry of a certain country, the EU, or the globe, implying that many further firms were impacted. Even $57.36 \%$ of the pandemic-related announcements in our dataset were of OEMs, $14.72 \%$ were of suppliers, and 27.92\% were sectoral. The OEMs with the most entries in our sample were the Renault-NissanMitsubishi alliance (12.69\%), the VW Group (8.12\%), and BMW (5.08\%).

Moreover, we looked into CEE's involvement and the share of German automotive firms in relation to the Covid-19 pandemic announcements. Central and Eastern European countries were engaged in $31.22 \%$ of these cases, while $28.29 \%$ of these announcements were connected to German automotive firms (Table 5). Thus, the CEE-related entries were slightly overrepresented in this subset, while those linked to the German automotive firms were relatively underrepresented compared to the full sample.

Table 5. Pandemic-related announcements with the involvement of CEE and German automotive firms

\begin{tabular}{|l|r|r|r|}
\hline \multicolumn{1}{|c|}{ Category } & \multicolumn{1}{c|}{ CEE } & German automotive firm & \multicolumn{1}{c|}{ Both } \\
\hline Number in full sample & 194 & 284 & 75 \\
\hline Number of Covid-19 related announcements & 64 & 58 & 19 \\
\hline Share (\%) in Covid-19 subset & 31.22 & 28.29 & 9.27 \\
\hline
\end{tabular}

Source: own study.

We also looked at the location affected by the announcements in our dataset. For many decisions the whole globe $(20.81 \%)$ or the EU $(10.66 \%)$ were concerned, and countrywise, Germany, Italy, and the United Kingdom appeared the most frequently. Of course, China, Japan, or the USA were also heavily concerned locations but our focus was on Europe.

What about the Covid-19 pandemic and decision types? These results were presented in Table 6 along the number and share of decisions in the Covid-19 subset, share in the decision type category, and CEE involvement. Concerning the pandemic-related decisions within the whole sample, $18.96 \%$ of all business decisions had some relation to Covid-19. However, based on our database, $87.29 \%$ of the decisions on temporary production decisions and $27.34 \%$ of the labour force decisions were made in connection with the pandemic. Almost one-tenth of the relocation-related announcements referred to Covid-19, although this only meant two occurrences. 
Most of the pandemic-related decisions belonged to the temporary production decision type $(60 \%)$. These were mostly temporary shutdowns, re-openings, and restarts or production volume decrease decisions, the latter due to health and safety or GVC reasons. Labour-force-related issues formed the second largest category (22.22\%), yet not all of these decisions covered layoffs. In some cases, labour force announcements concerned extra bonuses paid to the workforce during the pandemic. All other related decisions had lower significance with less than $10 \%$ share in the subset. Plant closures, relocations, and new location decisions were the least prevalent.

Table 6. Covid-19 related decisions, by type

\begin{tabular}{|c|c|c|c|c|c|c|c|c|c|c|c|}
\hline Types & 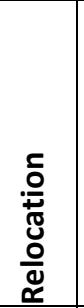 & 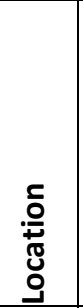 & 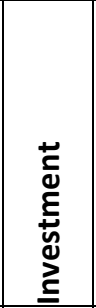 & 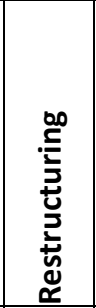 & 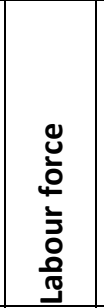 & 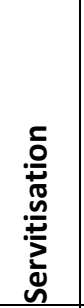 & 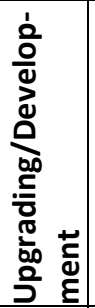 & 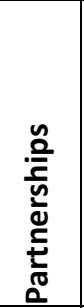 & 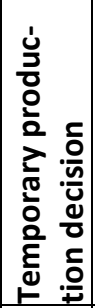 & 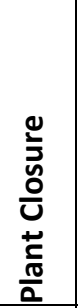 & 宽 \\
\hline Decisions (number) & 2 & 2 & 10 & 6 & 38 & 0 & 5 & 4 & 103 & 1 & 171 \\
\hline Decisions (share, \%) & 1.17 & 1.17 & 5.85 & 3.51 & 22.22 & 0.00 & 2.93 & 2.34 & 60.23 & 0.58 & 100 \\
\hline $\begin{array}{l}\text { Covid-19 related decisions } \\
\text { (share in whole category) }\end{array}$ & 9.09 & 3.13 & 5.78 & 14.28 & 27.34 & 0.00 & 2.69 & 3.60 & 87.29 & 5.88 & 18.96 \\
\hline CEE involvement (number) & 0 & 2 & 7 & 2 & 15 & 0 & 2 & 0 & 37 & 0 & 65 \\
\hline CEE involvement (share, \%) & 0.00 & 3.08 & 10.76 & 3.08 & 23.08 & 0.00 & 3.08 & 0.00 & 56.92 & 0.00 & 100 \\
\hline $\begin{array}{l}\text { CEE involvement } \\
\text { (\% of Covid-19 related decisions) }\end{array}$ & 0.00 & 100 & 70 & 33.33 & 39.47 & 0.00 & 40 & 0.00 & 26.81 & 0.00 & 38.01 \\
\hline
\end{tabular}

Source: own study.

Although we found only 10 decisions in connection with investments in our Covid-19 subset, they were worth considering as - in the majority of these cases - only few (three) decisions were delays of planned investments, while the majority (seven) referred to investments in digitalisation and electrification. Thus, these decisions could have been seen as ways of coping with the damages and losses caused by Covid-19. Furthermore, they were signals of firms concentrating on the future and on longer-term developments rather than short-term disturbances. Upgrading/development (five) and partnership (four) decisions - taken even in times of the uncertainty brought about by the pandemic - also supported this statement.

Regarding Covid-19 decisions with CEE involvement along firms' country of origin breakdown, $29.69 \%$ of these decisions were made by German automotive firms. Japanese (14.06\%), Korean, and French (4.69\% each) industry players also appeared in pandemic-related decisions in CEE (Japanese and Korean mostly through suppliers). Temporary production decisions dominated the cases with CEE involvement in the pandemic-related subsample, implying that CEE was not an exception in this respect. In our sample, $23.08 \%$ of Covid-19 decisions in CEE countries were made in connection with the labour force, mostly covering layoffs. To save costs, many OEMs and even more suppliers decided to reduce the labour force base either worldwide or just in CEE. Large cutbacks occurred at Continental and Bosch in Hungary or Renault in Slovenia, among others. Investments came third in the CEE region, making up $10.76 \%$ of pandemic-related CEE announcements. In fact, $70 \%$ of all Covidrelated investment decisions in our sample involved the CEE region; moreover, all the new location decisions were CEE related. This is a further proof that CEE could remain an important region for automotive firms, even during the pandemic.

The fact that among the analysed business decisions, the topics of electrification and digitalisation were highly prevalent is in line with the main findings of literature (Casper \& Sundin, 2020; Urbach \& Röglinger, 2018). The third most frequent topic in our sample was the Covid-19 pandemic. Upon the outbreak of the coronavirus epidemic evolving into a pandemic, Simonazzi et al. (2020) foresaw that it would likely become an accelerator of existing trends in the automotive sector. Our sample of business decisions justifies this projection. At the same time, our finding that Covid-19 
induced temporary production decisions and other decisions, affecting the labour force is in line with the findings of Betti \& Hong (2020) or Żak \& Garncarz (2020).

Upgrading and development, investment, and labour-force-related decisions dominated our sample - the three made $55.21 \%$ of all decisions. Investment in innovation and development in downturns is also revealed by Kaszowska and Mojsa (2020). The dominance of German manufacturers in the CEE region comes by no surprise (Pavlínek, 2015; Demertzis \& Masllorens, 2020). However, based on our sample, the CEE region importantly does not appear to have a second-rank position, which contradicts the mainstream conclusion of the truncated development literature emphasising the controversial nature of FDI-based growth in peripheral Europe (Pavlínek, 2015), and also challenges the idea of the CEE region's desperate dependence on the West (Nölke \& Vliegenthart, 2009). Nevertheless, increasing investment in the automation of peripheral manufacturing plants is lately indicated by Drahokoupil (2020).

\section{CONCLUSIONS}

In our study, we aimed at examining how Covid-19 has affected the European automotive industry, with a special focus on Central and Eastern Europe. In our analysis, we tried to emphasise the relationship between the pandemic and the ongoing sectoral megatrends (i.e. electrification and digitalisation), relying on our self-collected sample of business announcements.

Coding our inputs has enabled us to carry out a complex analysis, aiming at verifying our hypotheses. Our first hypothesis concerned the fundamental effect of the Covid-19 pandemic on the European automotive industry. Approximately $30 \%$ (205 out of 703 ) of the items in our sample are related to Covid-19, which already reveals its importance. Actually, 27 of these cases involved electrification in parallel, which implies that the Covid-19 pandemic may be an opportunity for firms to accelerate transformation to electrification. On the other hand, 25 pandemic-related announcements concerned layoff (one-third of all the items under layoff), spectacularly revealing the negative effects of Covid-19 in the European automotive industry. In terms of business decision types, those related to Covid-19 were heavily dominated (60.59\%) by temporary production decisions. On the other hand, $87.29 \%$ of all the temporary business decisions in our sample were Covid-19 related. These numbers highlight the shortterm effects of the pandemic in the industry that were mainly negative in nature. Nevertheless, the fact that the global shortage of semiconductor chips has driven automotive firms to make decisions resulting in weaker dependence on Asian producers, even by establishing chip production plants in Europe, implies that - along these lines - the pandemic may have long-term effects on the sector. Overall, we consider our first hypothesis as verified.

In terms of our second hypothesis, we have demonstrated the intensive involvement of the CEE region in the whole sample and in the Covid-19 related subset. Based on our research, CEE as a location for automotive industrial actors lost none of its attractiveness. In addition, the trends in this region show no diverse pattern but fit in the main European and global trends, which may be surprising and can be a sign of the CEE region's upgrade within the European automotive industrial structure, from a peripheral to a more central status. Accordingly, we accept our second hypothesis as well.

Our third hypothesis addressed the interference of Covid-19 with the transformational megatrends of digitalisation and electrification in the industry. In this respect, we foresaw unexpected advancements. Our analysis did not reveal this element. Nevertheless, the Covid-19 induced crisis taken as an opportunity by business actors was traceable in our sample, especially by firms who undertook development investments and engaged in forward looking partnerships, many times with firms from the ICT sector, which is a rather new phenomenon. Many of these advancements may well have taken effect without Covid-19; however, the pandemic has proven to be a trigger in this situation. Consequently, we partly accept our third hypothesis.

Based on our research, our main suggestion for business is to concentrate on the sectoral megatrends, and never miss the long run from the decision-making horizon. Through such an approach, Covid-19 can also be viewed as an opportunity to introduce developments. One policy implication deriving from our research is that the actors of the automotive industry were rather responsive both to 
the ongoing transformation and to the pandemic, so the winning policy targeting this sector may be to ensure an enabling environment that fosters change undertaken by the business actors themselves.

The main limitation of our research is the lack of representativeness and completeness of our sample. Nevertheless, trends can be drawn from the sample due to its large size. A further limitation is our negligence of government decisions and other policy measures, especially those related to the Covid19 pandemic with a direct or indirect effect on the automotive sector; this has been a deliberate decision as we focused on business decisions. As we were monitoring international and Hungarian sources, we may have missed announcements only available in other national languages and other sources of information. Last but not least, even if we strove for objectivity, our primary research may be limited by a certain degree of inevitable subjectivity.

Regarding the possible directions of future research, our sample can be extended by the involvement of government decisions and further policy measures targeting the European automotive industry, be it directly or indirectly. Going further in depth with research on business decisions, potentially on a selective case study basis, future studies could investigate whether the pandemic led to new projects and operational changes or challenged the current mode of operation at firms' level. Certainly, should any future events similar to the Covid-19 pandemic unfold with a comparable potential to shape the life of businesses, the amplification of the sample involving these newly evolving aspects is also a way to go forward.

\section{REFERENCES}

ACEA (2018). The Automobile Industry Pocket Guide 2018-2019. Brussels, Belgium: European Automobile Manufacturer Association. Retrieved from https://www.acea.auto/nav/?content=publications\&search=\%22pocket\%20guide\%22\&orderby=date on January 09, 2021.

ACEA (2020a). Interactive map: Production impact of COVID-19 on the European auto industry. Brussels, Belgium: European Automobile Manufacturer Association. Retrieved from https://www.acea.be/news/article/interactive-map-production-impact-of-covid-19-on-the-european-auto-industry on January 09, 2021.

ACEA (2020b). Interactive map: COVID-19 impact on EU automobile production, full-year 2020. Brussels, Belgium: European Automobile Manufacturer Association Retrieved from: https://www.acea.be/news/article/interactive-map-covid-19-impact-on-eu-automobile-production-full-year-2020 on January 10, 2021.

Belniak, M. (2015). Factors Stimulating Internationalisation of Firms: An Attempted Holistic Synthesis. Entrepreneurial Business and Economics Review, 3(2), 125-140. https://doi.org/10.15678/EBER.2015.030209

Betti, F., \& Hong, K.P. (2020). Coronavirus is disrupting global value chains Here's how companies can respond. Cologny, Switzerland: World Economic Forum Retrieved from https://www.weforum.org/agenda/2020/02/how-coronavirus-disrupts-global-value-chains/?fbclid=IwAROd8Xj3zlgi3dIDh95dEDZliob1B-VgVbyUt2\%E2\%80\%A6 on January, 092021.

Böhm, A. (2004). Theoretical Coding: Text Analysis in Grounded Theory. In Flick, U., Kardoff, E., \& Steinke, I. (Eds.), A Companion to Qualitative Research, (pp. 270-275). London, UK: SAGE Publications

Casper, R., \& Sundin, E. (2020). Electrification in the automotive industry: effects in remanufacturing. Journal of Remanufacturing, Retrieved from https://link.springer.com/article/10.1007/s13243-020-00094-8 on February 07, 2021.

Cieślik, A. (2017). Determinants of MNE Activity in Poland: The Case of Firms from EU-15. Entrepreneurial Business and Economics Review, 5(1), 151-167, https://doi.org/10.15678/EBER.2017.050109

Demertzis, M., \& Masllorens, G. (2020). The cost of coronavirus in terms of interrupted global value chains. Bruegel Blog Post, Brussels, Belgium: Bruegel Retrieved from https://www.bruegel.org/2020/03/the-cost-ofcoronavirus-in-terms-of-interrupted-global-value-chains/?fbclid=IwAROII3f2mt600lcngi-YpEBdVve14n\%E2\%80\%A6 on January, 092021.

Dorożyński, T., Dobrowolska, B., \& Kuna-Marszałek, A. (2020). Institutional Quality in Central and East European Countries and Its Impact on FDI Inflow. Entrepreneurial Business and Economics Review, 8(1), 91-110. https://doi.org/10.15678/EBER.2020.080105 
Drahokoupil, J. (2020). Introduction: Digitalisation and automotive production networks in Europe. In Drahokoupil, J. (Ed.), The challenge of digital transformation in the automotive industry-Jobs, upgrading and prospects for development (pp. 7-22.). Brussels: ETUI Retrieved from https://www.etui.org/publications/challenge-digital-transformation-automotive-industry on June 1, 2021.

Drelich-Skulska, B., \& Bobowski, S. (2021). Intra-industry trade and implications of the European Union-Japan Economic Partnership Agreement from the perspective of the automotive industry. Entrepreneurial Business and Economics Review, 9(2), 183-206. https://doi.org/10.15678/EBER.2021.090212

Dutt, D., Natarajan, V., Wilson, A., \& Robinson, R. (2020). Steering into Industry 4.0 in the automotive sector. In Kaji, J., Saini, K., Khan, A., Gangopadhyay, N., George, A., Bhat, R., \& Devan, P. (Eds.), Industry 4.0 in automotive: Digitizing the end-to-end automotive value chain (pp. 7-10). London UK: Deloitte Insights.

EC (2021). Economic Forecasts and Trends. Brussels, Belgium: European Commission Retrieved from https://ec.europa.eu/info/statistics/economic-forecasts-and-trends_en on March 20, 2021.

Farkas, B. (2011). The Central and Eastern European model of capitalism. Post-Communist Economies, 23(1), 1534. https://doi.org/10.1080/14631377.2011.546972

Giffi, C.A., Vitale, J., Schiller, T., \& Robinson, R. (2020). Who's going to pay for the future mobility? In Kaji, J., Saini, K., Khan, A., Gangopadhyay, N., George, A., Bhat, R., \& Devan, P. (Eds.), Industry 4.0 in automotive: Digitizing the end-to-end automotive value chain (pp. 2-6.). London UK: Deloitte Insights.

Götz, M., Jankowska, B., Matysek-Jędrych, A., \& Mroczek-Dąbrowska, K. (2018). Governmental change and FDI inflow to Poland and Hungary in 2010-2016. Entrepreneurial Business and Economics Review, 6(1), 153-173. https://doi.org/10.15678/EBER.2018.060109

Kaszowska-Mojsa, J. (2020). Innovation strategies of manufacturing companies during expansions and slowdowns. Entrepreneurial Business and Economics Review, 8(4), 47-66. https://doi.org/10.15678/EBER.2020.080403

Kinnunen, J., Georgescu, I., Hosseini, Z., \& Androniceanu, A.-M. (2021). Dynamic indexing and clustering of government strategies to mitigate Covid-19. Entrepreneurial Business and Economics Review, 9(2), 7-20. https://doi.org/10.15678/EBER.2021.090201

Leering, R., \& Spakman, T. (2020). Countries hit most by the coronavirus value chain shock. ING Economic and Financial Analysis, ING, Retrieved from https://think.ing.com/articles/countries-hurt-most-by-covid-19global-value-chain-shock/ on February 09, 2021.

Linneberg, M. S., \& Korsgaard, S. (2019). Coding qualitative data: a synthesis guiding the novice. Qualitative Research Journal, 19(3), 259-270. https://doi.org/10.1108/QRJ-12-2018-0012

Makieła, K., Wojciechowski, L., \& Wach, K. (2021). Effectiveness of FDI, technological gap and sectoral level productivity in the Visegrad Group. Technological and Economic Development of Economy, 27(1), 149-174. https://doi.org/10.3846/tede.2020.14017

Molnár, E. (2013). Egy dinamikus iparág foglalkoztatási hatásainak földrajzi aspektusai: a magyarországi autóipar esete, Területi Statisztika, 53(4), 322-339. Retrieved from https://www.ksh.hu/docs/hun/xftp/terstat/2013/04/molnar.pdf on December 15, 2020.

Nölke, A., \& Vliegenthart, A. (2009). Enlarging the Varieties of Capitalism: The Emergence of Dependent Market Economies in East Central Europe. World Politics, 61(4), 670-702. https://doi.org/10.1017/S0043887109990098

Pavlínek, P. (2015). Foreign direct investment and the development of the automotive industry in central and eastern Europe. In Galgóczi B., Drahokoupil J., \& Bernaciak M. (Eds.), Foreign investment in eastern and southern Europe after 2008 - Still a lever of growth? (pp. 209-255). Brussels, Belgium: ETUI Retrieved from: https://www.etui.org/sites/default/files/15\%20Foreign\%20invest\%20Galgoczi\%20Web\%202\%20version.pdf on December 22, 2020.

Pavlínek, P., Aláez-Aller, R., Gil-Canaleta, C., \& Ullibarri-Arce, M. (2017). Foreign Direct Investment and the development of the automotive industry in Eastern and Southern Europe. ETUI Working Paper No. 2017.03, Brussels, Belgium: European Trade Union Institute Retrieved from https://www.researchgate.net/publication/324665544_Foreign_Direct_Investment_and_the_Development_of_the_Automotive_Industry_in_Eastern_and_Southern_Europe on December 20, 2020.

Pavlínek, P., \& Guzik, R. (2009). Industrial Upgrading through Foreign Direct Investment in Central European Automotive Manufacturing. European Urban and Regional Studies, 16(1), 46-63. https://doi.org/10.1177/0969776408098932 
Rechnitzer, J., Hausmann, R., \& Tóth, T. (2017). Insight into the Hungarian Automotive Industry in International Comparison. Financial and Economic Review, 16(1), 119-142. Retrieved from https://econpapers.repec.org/RePEc:mnb:finrev:v:16:y:2017:i:1:p:119-142 on December 15, 2020.

Ricci, A. (2019). Is There Social or Monetary Dumping in the European Union? Manufacturing Competitiveness in Central and Eastern Europe. Entrepreneurial Business and Economics Review, 7(1), 159-180. https://doi.org/10.15678/EBER.2019.070109

Saldaña, J. (2009). The coding manual for qualitative researchers. London, UK: SAGE Publications

Saldaña, J. (2015). The coding manual for qualitative researchers 3rd ed. Thousand Oaks, CA: Sage

Simonazzi, A., Sanginés, J. C., \& Russo, M. (2020). The Future of the Automotive Industry: Dangerous Challenges or New Life for a Saturated Market? Intereconomics Working Paper No. 141, Intereconomics Institute for New Economic Thinking

UNCTAD (2020a). Global trade impact of the coronavirus (COVID-19) epidemic. UNCTAD Trade and Development Report, No. UNCTAD/DITC/INF/2020/1. Geneva, Switzerland: United Nations Conference on Trade and Development Retrieved from: https://unctad.org/system/files/official-document/ditcinf2020d1.pdf on February 10, 2021.

UNCTAD (2020b). Impact of the Coronavirus Outbreak on Global FDI. UNCTAD Investment Trends Monitor Special Issue March 2020. Geneva, Switzerland: United Nations Conference on Trade and Development Retrieved from: https://unctad.org/system/files/information-document/diae_gitm34_coronavirus_8march2020.pdf on February 10, 2021.

Urbach, N., \& Röglinger, M. (2018). Introduction to Digitalization Cases: How Organization Rethink Their Business for the Digital Age. In Urbach, N., \& Röglinger, M. (Eds.), Digitalization Cases: How Organization Rethink Their Business for the Digital Age (pp. 1-12). Cham, Switzerland: Springer International Publishing.

Vosta, M., \& Kocourek, A. (2016). Competitiveness of the European Automobile Industry in the Global Context.Politics in Central Europe, 13(1), 69-86. https://doi.org/10.1515/pce-2016-0023

Żak, M., \& Garncarz, J. (2020). Economic policy towards the challenges of the COVID-19 pandemic in selected European Union countries. International Entrepreneurship Review, 6(4), 21-34. https://doi.org/10.15678/IER.2020.0604.02 


\section{Authors}

The contribution share of authors is equal and amounted to $50 \%$ for each of them.

\section{Anita Pelle}

Associate Professor at the University of Szeged. She holds a PhD in Economics (2010). She received a postdoctoral scholarship from the National Centre of Excellence of Hungary in 2013-2014 and has held a Jean Monnet Chair since 2014. She teaches on and studies the economy of the EU, the European economic integration process, the history of European economic thought, the EU internal market and its regulation, and lately, the internal EU divide. She has also been visiting professor at Université d'Angers (France), Université Jean Moulin Lyon III (France), Universitá di Pavia (Italy), Vysoká Škola Ekonomická v Praze (Czech Republic), Universitá di Macerata (Italy), and Uniwersytet Warszawski (Poland).

Correspondence to: Anita Pelle, PhD, the University of Szeged, Faculty of Economics and Business Administration, Kálvária Avenue 1, 6722 Szeged, Hungary, e-mail: tabajdi.gabriella@eco.u-szeged.hu

ORCID (1) http://orcid.org/0000-0001-9115-4264

\section{Gabriella Tabajdi}

PhD Student and junior researcher at the Faculty of Economics and Business Administration of the University of Szeged. She holds an MSc in International Economy and Business (University of Szeged) and an MSc in International Business and Entrepreneurship (Universitá di Pavia). Her research focuses on the process of European integration, the internal market of the European Union, and international business and location decisions.

Correspondence to: Ms. Gabriella Tabajdi, University of Szeged, Faculty of Economics and Business Administration, Kálvária Ave-nue 1, 6722 Szeged, Hungary, e-mail: tabajdi.gabriella@eco.u-szeged.hu ORCID (i) http://orcid.org/0000-0002-4059-0514

\section{Acknowledgements and Financial Disclosure}

This research was supported by the project no. EFOP-3.6.2-16-2017-00007, titled "Aspects on the development of intelligent, sustainable and inclusive society: social, technological, innovation networks in employment and digital economy." The project was supported by the European Union, co-financed by the European Social Fund, and the budget of Hungary.

\section{Conflict of Interest}

The authors declare that the research was conducted in the absence of any commercial or financial relationships that could be construed as a potential conflict of interest.

\section{Copyright and License}

This article is published under the terms of the Creative Commons

Attribution - NoDerivs (CC BY-ND 4.0) License

http://creativecommons.org/licenses/by-nd/4.0/ 
